\title{
Kesiapan Wanita Usia 45-55 Tahun dalam Menghadapi Perubahan Masa Menopause
}

\author{
Ni'matul Ulya, Putri Andanawarih \\ Email: renex_cubby@yahoo.co.id \\ DIII Kebidanan, Akademi Kebidanan Harapan Ibu Pekalongan, Indonesia \\ Jl. Sriwijaya No. 7 Pekalongan \\ Telp/Fax. (0285) 4416108
}

\begin{abstract}
Abstrak
Menopause merupakan suatu proses peralihan dari masa produktif menuju perlahan-lahan ke masa nonproduktif yang disebabkan berkurangnya hormon estrogen dan progesteron. Usia rata-rata sebagian besar wanita melalui masa menopause adalah antara umur 45-55 tahun. Beberapa wanita menganggap menopause merupakan hal yang menakutkan, kekhwatiran ini berawal dari pemikiran bahwa dirinya akan menjadi tidak sehat sehingga muncul rasa cemas. Di Indonesia, pada tahun 2025 diperkirakan akan ada 60 juta perempuan menopause. Kesiapan dalam menghadapi menopause adalah suatu keadaan ibu untuk mempersiapkan dirinya dalam menghadapi menopause baik secara fisik, mental maupun psikologisnya Tujuan penelitian ini adalah untuk mengetahui kesiapan wanita usia 45-55 tahun dalam menghadapi perubahan masa menopause di Kelurahan Kuripan Yosorejo. Penelitian ini merupakan penelitian kuantitatif dengan rancangan penelitian cross sectional dan menggunakan uji statistik chi square. Hasil penelitian diperoleh nilai $\mathrm{p}$ value $0,01<\alpha(0,05)$ yang berarti ada hubungan antara pengetahuan tentang menopause terhadap kesiapan menghadapi perubahan masa menopause. Dengan penelitian ini, diharapkan ibu menopause dapat menambah pengetahuan tentang kesehatan reproduksi khususnya tentang menopause dengan banyak membaca buku tentang menopause atau melalui media informasi lainnya sehingga dapat meningkatkan pemahaman tentang bagaimana cara menghadapi menopause dan mengurangi keluhan-keluhan menjelang menopause, terutama bagi ibu menopause dengan tingkat pengetahuan yang kurang.
\end{abstract}

Kata Kunci: kesiapan; perubahan masa menopause.

\begin{abstract}
Menopause is a process of transition from the productive period to the nonproductive period due to the reduction in the hormones estrogen and progesterone. The average age of most women going through menopause is between the ages of 45 and 55. Some women consider menopause to be a frightening thing, this worry comes from the thought that they will become unhealthy so that they feel anxious. In Indonesia, by 2025 it is estimated that there will be 60 million menopausal women. Readiness to face menopause is a condition for mothers to prepare themselves for menopause both physically, mentally and psychologically. The purpose of this study was to determine the readiness of women aged 45-55 years in facing menopause changes in Kuripan Yosorejo Village. This research is a quantitative study with a cross sectional study design and using the chi square statistical test. The results obtained $p$ value $0.01<\alpha(0.05)$, which means that there is a relationship between knowledge of menopause and readiness to face changes in menopause. With this research, it is hoped that menopausal mothers can increase their knowledge about reproductive health, especially about menopause by reading many books about menopause or through other information media so that it can increase understanding of how to deal with menopause and reduce complaints before menopause, especially for menopausal mothers at a level lack of knowledge.
\end{abstract}

Keywords: readiness; changes in the menopause period. 
Jurnal Kebidanan Harapan Ibu Pekalongan

\section{Pendahuluan}

Memasuki usia 40 tahun sering disebut juga masa transisi menjelang hari tua dan sering disebut masa dewasa madya (1). Menopause merupakan suatu hal yang paling banyak dibicarakan, dipermasalahkan dan membingungkan bagi sebagian wanita. Mengalami menopause berarti memasuki masa tua, masa non produktif. Menopause diartikan sebagai masa penghentian menstruasi untuk selamanya. Menopause merupakan suatu proses peralihan dari masa produktif menuju perlahan-lahan ke masa nonproduktif yang disebabkan berkurangnya hormon estrogen dan progesteron ${ }^{(2)}$.

Usia rata-rata sebagian besar wanita melalui masa menopause adalah antara umur 45-55 tahun ${ }^{(3)}$. Data dari World Health Organization (WHO) tahun 2014 yang menyatakan pada tahun 2030 jumlah perempuan di seluruh dunia yang memasuki masa menopause diperkirakan mencapai 1,2 miliar orang. Di Indonesia, pada tahun 2025 diperkirakan akan ada 60 juta perempuan menopause ${ }^{(4)}$.

Perubahan yang biasa terjadi pada masa menopause antara lain semburan rasa panas (hot flushes) dan keringat pada malam hari, kelelahan, insomnia, kekeringan kulit dan rambut, sakit dan nyeri pada persendian, sakit kepala, palpitasi (denyut jantung cepat dan tidak teratur), berat badan bertambah, bentuk tubuh yang berubah ${ }^{(5)}$.

Menurut hasil penelitian yang dilakukan oleh Hekhmawati (2016) menunjukkan bahwa perubahan fisik yang sering terjadi pada wanita menopause yaitu hot flush $(81,3 \%)$, insomnia $(65,3 \%)$, vagina menjadi kering $(58,7 \%)$, dan nyeri sendi
$(57,3 \%)^{(6)}$. Perubahan fisik yang dialami pada wanita menopause tersebut dapat mempengaruhi kondisi psikologis. Perubahan psikologis tersebut muncul karena perubahan fisik serta hormonal yang berakibat pada peningkatan sensitivitas pada wanita ${ }^{(7)}$.

Beberapa wanita menganggap menopause merupakan hal yang menakutkan, kekhwatiran ini berawal dari pemikiran bahwa dirinya akan menjadi tidak sehat sehingga muncul rasa cemas. Perasaan tertekan atau kecemasan yang dialami individu, termasuk kondisi menopause yang dialami wanita, mendorong wanita untuk memecahkan masalah melalui cara mencari bantuan dan dukungan dari keluarga dan teman-temannya ${ }^{(8)}$. Kesiapan dalam menghadapi menopause adalah suatu keadaan ibu untuk mempersiapkan dirinya dalam menghadapi menopause baik secara fisik, mental maupun psikologisnya. Penelitian ini bertujuan untuk mengetahui kesiapan wanita usia 4555 tahun dalam menghadapi perubahan masa menopause di Kelurahan Kuripan Yosorejo.

Berdasarkan survey awal yang dilakukan peneliti di Kelurahan Podosugih Kota Pekalongan dengan cara wawancara pada 15 wanita pramenopause didapatkan hasil bahwa terdapat 3 orang wanita pra menopause mengetahui tanda gejala menopause yaitu seperti haid tidak teratur, rasa panas pada badan terutama malam hari, sulit tidur dan emosi terganggu sehingga mereka cukup siap dalam mengahdapi masa menopause. Sedangkan 12 orang ibu pramenopause lainnya tidak mengetahui tanda gejala tentang menopause sehingga menimbulkan kecemasan dan mereka mengatakan belum siap dalam menghadapi menopause karena mereka tidak 
Jurnal Kebidanan Harapan Ibu Pekalongan

tahu atau kurang paham serta takut akan perubahan yang akan terjadi setelah menopause.

\section{Metode Penelitian}

Jenis penelitian yang digunakan adalah dengan pendekatan kuantitatif dengan rancangan penelitian cross sectional. Populasi dalam penelitian ini adalah seluruh wanita usia 45-55 tahun pada bulan Maret 2020 yang bertempat tinggal di Kelurahan Kuripan Yosorejo sebanyak 100 orang dan perngambilan sampel dilakukan dengan menggunakan rumus Solvin sehingga didapat sampel 50 wanita usia 45-55 tahun di Kelurahan Kuripan Yosorejo. Analisis data yang digunakan dalam penelitian ini meliputi analisis univariat untuk mengetahui karakteristik sampel dan analisis bivariat menggunakan uji chi square.

\section{Hasil dan Pembahasan}

a. Karakteristik responden berdasarkan umur

Tabel 1. Karekteristik responden berdasarkan umur

\begin{tabular}{ccc}
\hline Umur & F & \% \\
\hline $45-48$ tahun & 11 & 22 \\
$49-52$ tahun & 23 & 46 \\
53 - 55 tahun & 16 & 32 \\
\hline Total & 50 & 100 \\
\hline
\end{tabular}

Karakteristik responden berdasarkan umur didapatkan hasil sebagian besar responden berada dalam rentang umur 4952 tahun sebanyak 23 orang (46\%), rentang 53-55 tahun sebanyak 16 orang $(32 \%)$ dan rentang umur 45-48 tahun ada 11 orang $(22 \%)$.

Umur adalah waktu hidup atau ada (sejak dilahirkan atau diadakan) ${ }^{(9)}$. Umur seseorang $\begin{array}{lcr}\text { yang } & \text { bertambah } & \text { dapat } \\ \text { membuat } & \text { perubahan } & \text { pada } \\ \text { aspek fisik } & \text { psikologis } & \text { dan } \\ \text { kejiwaan. } & \text { Dalam } & \text { aspek } \\ \text { psikologis } & \text { taraf } & \text { berfikir }\end{array}$ seseorang semakin matang dan dewasa ${ }^{(10)}$. Berkaitan dengan menopause, usia akan mempengaruhi perubahan fisik yang terjadi. Semakin bertambahnya usia maka akan semakin besar juga perubahan yang dialami.

Hasil penelitian ini sejalan dengan hasil penelitian dari Wahyuni (2020) dengan judul "Faktor-Faktor Yang Mempengaruhi Kesiapan Wanita Usia 40-50 Tahun Dalam Menghadapi Menopause Di Kecamatan Langsa Timur Kota Langsa", menyatakan adanya hubungan umur dengan kesiapan dalam wanita dalam mengahdapi menopause. Wanita yang berumur lebih tua berpeluang lebih siap dalam menghadapi menopause ${ }^{(11)}$.

b. Karakteristik responden berdasarkan pendidikan

Tabel 2. Karekteristik responden berdasarkan pendidikan

\begin{tabular}{ccc}
\hline Pendidikan & F & (\%) \\
\hline Dasar & 13 & 26 \\
Menengah & 32 & 64 \\
Tinggi & 5 & 10 \\
\hline Total & 50 & 100 \\
\hline
\end{tabular}

Karakteristik responden berdasarkan tingkat pendidikan menunjukkan bahwa lebih dari separuh responden berpendidikan menengah (tingkat SMA) sebanyak 32 responden $(64 \%)$, berpendidikan dasar (tingkat SD dan SMP) sebanyak 13 responden (26\%) dan pendidikan tinggi (tingkat 
Jurnal Kebidanan Harapan Ibu Pekalongan

akademi/sarjana) sebanyak 5 responden $(10 \%)$.

Pendidikan mempengaruhi proses belajar, makin tinggi pendidikan seeorang makin mudah orang tersebut untuk menerima informasi. Dengan pendidikan tinggi maka seseorang akan cenderung untuk mendapatkan informasi, baik dari orang lain maupun dari media massa ${ }^{(12)}$.

Tingginya pendidikan dapat mempengaruhi minat ibu untuk menetahui secara dini persiapan fisik maupin psikis dalam memasuki masa menopause. Dalam penelitian ini pendidikan ibu dibedakan dalam 3 kategori yaitu pendidikan dasar (SD dan SMP), pendidikan menengah (SMA) dan pendidikan tinggi (perguruan tinggi).

c. Karakteristik responden berdasarkan pekerjaan

Tabel 3. Karekteristik responden berdasarkan pekerjaan

\begin{tabular}{lcc}
\hline \multicolumn{1}{c}{ Pekerjaan } & F & $\%$ \\
\hline Ibu Rumah Tangga & 11 & 22 \\
Wiraswasta/dagang & 20 & 40 \\
Buruh & 15 & 30 \\
PNS & 4 & 8 \\
\hline Jumlah & 50 & 100 \\
\hline
\end{tabular}

Sebagian responden di Kelurahan Kuripan Yosorejo merupakan wanita yang bekerja baik sebagai pedagang, buruh atau PNS. Hal ini mempengaruhi ibu dalam mendapatkan ataupun mencari informasi tentang kesiapan menghadapi menopause, Ibu yang bekerja kurang dalam memikirkan bagaimana cara melakukan kesiapan dalam menghadapi menopause karena sibuk dengan pekerjaannya.
Hal ini sesuai dengan penelitian Nurningsih (2012) yang dikutip oleh Indah (2019) dimana hasil penelitian tersebut menyebutkan bahwa ibu premeniopause yang bekerja sebagai ibu rumah tangga memiliki kesempatan untuk bersosialisasi dan menyerap informasi kesehatan. Wanita yang bekerja tidak sempat memikirkan ganguan menjelang menopause karena kesibukannya (13)

d. Karakteristik responden berdasarkan pengetahuan tentang menopause

Tabel 4. Karekteristik responden berdasarkan pengetahuan tentang menopause

\begin{tabular}{lcc}
\hline $\begin{array}{c}\text { Pengetahuan } \\
\text { tentang } \\
\text { menopause }\end{array}$ & F & $\%$ \\
\hline Baik & 33 & 66 \\
Kurang & 17 & 34 \\
\hline Jumlah & 50 & 100 \\
\hline
\end{tabular}

Hasil

penelitian menunjukkan sebagian besar ibu memiliki pengetahuan yang baik tentang menopause. Salah satu faktor yang mempengaruhi kesiapan dalam mengdapi menopause adalah pengetahuan. Pengetahuan merupakan hasil tahu seseorang terhadap objek melalui panca indra yang dimilikinya (mata, hidung, telinga, dan sebagainya). Pengindraan dipengaruh oleh intensitas perhatian dan persepsi terhadap objek ${ }^{(14)}$. Ibu yang memiliki pengetahuan kesehatan lebih baik akan lebih siap dalam menghadapi masa 
Jurnal Kebidanan Harapan Ibu Pekalongan

menopause, sehingga dapat disimpulkan pengetahuan yang baik membantu ibu memahami dan mempersiapkan diri menjalani menopause ${ }^{(15)}$.

e. Karakteristik Responden Berdasarkan Kesiapan menghadapi Menopause

Tabel 5. Karekteristik responden berdasarkan kesiapan menghadapi menopause

\begin{tabular}{lcc}
\hline $\begin{array}{c}\text { Pengetahuan } \\
\text { tentang menopause }\end{array}$ & F & $\%$ \\
\hline Siap & 30 & 60 \\
Tidak Siap & 20 & 40 \\
\hline Jumlah & 50 & 100 \\
\hline
\end{tabular}

Mayoritas responden telah siap dalam menghadapi menopause sebanyak 30 responden $(60 \%)$ dan tidak siap menghadapi menopause sebanyak 20 responden (40\%). Menurut Nugraha, faktor yang mempengaruhi kesiapan wanita dalam menghadapi menopause adalah psikis, peran keluarga, informasi dan budaya. Sedangkan menurut Notoadmojo, faktor yang mempengaruhi kesiapan wanita dalam menghadapi menopause adalah pendidikan, umur, pekerjaan, sosial ekonomi dan pengetahuan ${ }^{(14)}$. f. Hubungan Pengetahuan tentang Menopause terhadap Kesiapan Menghadapi Menopause

Tabel 6. Karekteristik pengetahuan tentang menopause terhadap kesiapan menghadapai menopause

Kesiapan dalam

\begin{tabular}{ccccc}
\multirow{2}{*}{ Pengetahuan } & \multicolumn{3}{c}{ menghadapi menopause } \\
\cline { 2 - 5 } & \multicolumn{2}{c}{ Siap } & \multicolumn{3}{c}{ Tidak Siap } \\
\cline { 2 - 5 } & $F$ & $\%$ & $F$ & $\%$ \\
\hline Baik & 24 & 80 & 9 & 45 \\
Kurang & 6 & 20 & 11 & 55 \\
\hline Total & 30 & 100 & 20 & 100 \\
\hline$p$ value 0,01 & & & &
\end{tabular}

Hasil analisis bivariat di atas menunjukkan bahwa responden yang berpengetahuan baik dan sudah siap dalam menghadapi menopause sebanyak 24 responden $(80 \%)$ dan tidak siap sebanyak 9 responden (45\%). Sedangkan berdasarkan hasil analisis dengan uji Chi Square Test didapatkan $\mathrm{p}$ value yaitu 0,010 ( $\mathrm{p}$ value $<0,05$ ) yang artinya $\mathrm{Ha}$ diterima sehingga dapat disimpulkan bahwa ada hubungan antara pengetahuan tentang menopause terhadap kesiapan responden dalam menghadapi menopause.

Menurut hasil penelitian ini, kesiapan ibu dalam menghadapi menopause dipengaruhi oleh pengetahun ibu tentang menopause secara ilmiah. Hasil penelitian menunjukkan sebagian besar responden memiliki pengetahuan yang baik mengenai menopause serta dalam tingkat pendidikan sebagian besar responden adalah menengah (SMP dan SMA). Dengan tingkat pengetahuan dan pendidikan yang baik pada seseorang akan lebih mudah menyerap informasi lebih baik dan mampu mengetahui 
Jurnal Kebidanan Harapan Ibu Pekalongan

perubahan-perubahan yang terjadi menjelang menopause, sehingga ibu lebih siap menghadapi menepause. Hasil penelitian ini sejalan dengan penelitian dari Sari (16) yang berjudul "Faktor-Faktor Yang Berhubungan Dengan Kesiapan Ibu Menghadapi Menopause Di Wilayah Kerja Puskesmas Guguk Panjang” dengan hasil yaitu adanya hubungan antara pengetahun dengan kesiapan ibu dalam menghadapi menopause.

Penelitian terkait lainnya dilakukan oleh Wahyuni (2020), salah satu hasil dari penelitiannya adalah adanya poengaruh pengetahuan terhadap kesiapan wanita menghadapi menopause. Responden dengan pengetahuan yang baik, lebih siap mennghadapi menopause dibandingkan dengan wanita dengan pengetahuan yang kurang ${ }^{(11)}$.

\section{Kesimpulan}

Karakteristik responden menunjukkan sebagian besar berada pada rentang umur 49-52 tahun (46\%), pendidikan responden pada tingkat menengah (64\%) dan pekerjaan sebagai wiraswasta/dagang $\quad(40 \%)$. Karakteristik responden berdasarkan pengetahuan tentang menopause sebagian besar sudah berpengetahuan baik (66\%). Karakteristik responden berdasarkan kesiapan dalam menghadapi menopause sebagian besar menyatakan siap (60\%).

Adanya hubungan antara pengetahuan tentang menopause terhadapa kesiapan menghadapi menopause dengan hasil $\mathrm{p}$ value $0,010(\mathrm{p}$ value $<0,05)$

\section{Daftar Pustaka}

[1] Damayanti, Euis Sri dan Alfi Purnamasari. Berpikir Positif dan Harga Diri pada Wanita yangmengalami Masa Premenopause. Jurnal Fakultas Psikologi Universitas AhmadDahlan Jalan Kapas No. 9. Humanitas, Vol. VIII No.2 Agustus. 149-150, 2011.

[2] Suparni, I.E \& Astutik, R.Y. Menopause masalah dan Penanganannya. Yogyakarta: Deepublish, 2016.

[3] Green. Menopause: New Insights For The Healthcare Professional. Acton Q. Ashton. Atlanta: Scholarly Editions, 2013.

[4] World Health Organization [Internet]. Bulettin of the world health otganization, 2016.

[5] Proverawati, A. Menopause dan sindrome premenopause. Yogyakarta: Nuha Medika, 2010.

[6] Hekhmawati, S. Gambaran perubahan fisik dan psikologis pada wanita menopause di Posyandu Desa Pabelan, 2016. [Online]. 15 Januari 2020. http://eprints.ums.ac.id/46220/2 4/NAS KAH\%2520PUBLIKASI.pdf\&s $\mathrm{a}=$

[7] Kumalasari, I., \& Andhyatoro, I. Kesehatan reproduksi untuk mahasiswa kebidanan dan keperawatan. Jakarta: Salemba Medika, 2012.

[8] Sari, Nining Loura. Faktor Yang Mempengaruhi Kesiapan Wanita dalam menghadapi Menopause. Jurnal of Nursing \& Biomolecular. Vol 3 No 2, Tahun 2018. 
Jurnal Kebidanan Harapan Ibu Pekalongan

[9] KBBI. Arti Kata Umur, 2016. [Online]. 14 Mei 2020. https://kbbi.web.id/umur accesed tanggal

[10] Fitriani, F., \& Lestari, A. Gambaran Pengetahuan Ibu Tentang Kebutuhan Gizi Pada Masa Menopause. JIKI Jurnal Ilmiah Kesehatan IQRA, 6(2), pp.142-145, 2018.

[11] Wahyuni, S., Yusrizal, Y., \& Wardiati, W. Faktor-Faktor Yang Mempengaruhi Kesiapan Wanita Usia 40-50 Tahun Dalam Menghadapi Menopause Di Kecamatan Langsa Timur Kota Langsa. Jukema (Jurnal Kesehatan Masyarakat Aceh), 6(1), pp.4-12, 2020.

[12] Budiman., dan Riyanto, A. Kapita Selekta Kuesioner. Salemba Medika, Jakarta, 2013.

[13] Indah, R. A. Hubungan Pengetahuan dengan Kesiapan Ibu dalam Menghadapi Menopause di Dusun Krandon Malangan Sumberagung Moyudan Sleman Yogyakarta (Doctoral dissertation, Universitas' Aisyiyah Yogyakarta), 2019.

[14] Kusumawati, S. Hubungan Tingkat Pengetahuan Dengan Kesiapan Ibu Dalam Menghadapi Menopause Di Desa Berangas Timur Kab. Barito Kuala. Bidan Prada: Jurnal Publikasi Kebidanan Akbid YLPP Purwokerto, 10(1), 2019.
[15] Novianti, R., \& Yunita, P.. Hubungan Pengetahuan Ibu Usia Premenopause tentang Menopause dengan Kesiapan Menghadapi Masa Menopause di Puskesmas Sei Pancur Kota Batam Tahun 2017. Zona Kebidanan: Program Studi Kebidanan Universitas Batam, 9(2), 2020.

[16] Sari, N. W., \& Yuniliza, Y. Faktor-Faktor Yang Berhubungan Dengan Kesiapan Ibu Menghadapi Menopause Di Wilayah Kerja Puskesmas Guguk Panjang. Menara Ilmu, 14(1), 2020. 